\title{
MICROBIOLOGICAL RISKS OF MILK SHAKE SOLD IN ASSIUT CITY RESTAURANTS
}

\author{
MARWA M.N. EL-GENDI and MARIUM F. MANSY \\ Animal Health Research Institute (Assiut Provincial Lab.) Food Hygiene Department and Microbiology Department
}

Received: 26 June 2017; $\quad$ Accepted: 13 July 2017

\begin{abstract}
An increase in the consumption of milk shakes has been observed in recent years all over the world. In this work, the hygienic quality of chocolate and fruity milk shake was examined. This study was carried out to evaluate presence of E.coli, Enterococcus spp. and Staph. aureus in 50 samples of milk shake which were collected from different restaurants in Assiut city. The obtained results revealed that E.coli, Enterococcus spp. and S. aureus were isolated and confirmed by chemical tests in percentages of $16 \%, 24 \% ; 20 \%, 44 \%$ and $12 \%$ and $24 \%$ of examined samples of chocolate and fruity milk shake, respectively. Concerning the mean values of total psychrotrophic count of chocolate milk shake and fruity milk shake were $9.9 \times 10^{3}$ and $1.2 \times 10^{4} \mathrm{CFU} / \mathrm{g}$, respectively. Whereas, it was indicated that total yeasts and molds counts of the examined samples of chocolate milk shake and fruity milk shake were $3.2 \times 10^{2}$ and $2.1 \times 10^{3}$, respectively. The obtained results revealed that the average counts of Enterococci were $4.9 \times 10^{3}$ and $1.1 \times 10^{4} \mathrm{CFU} / \mathrm{g}$ in the examined chocolate and fruity milk shake samples, respectively. In general the analysis indicates unsatisfactory quality of milk shakes and need to be microbiologically controlled by regulatory authorities and the public health significance of isolated strains as well as suggested control measures were discussed.
\end{abstract}

Key words: Microbiological Risks, Milk Shake, Restaurants

\section{INTRODUCTION}

Milk has played a major contribution in the human diet in many different countries across the world. Therefore, it is not surprising that considerable attention has been paid over many years to improve milk quality and in particular the hygienic quality. Bacterial contamination in milk can reduce the raw milk quality and create health hazards especially when the milk is contaminated with some certain species of bacteria with their associated enzymes and toxins that may survive pasteurization (Oliver et al., 2005). Microbiology to the dairy industry is an important issue, as recent outbreaks of food-borne illness were recorded as a result of consumption of milk and dairy products that had been contaminated with pathogenic organisms or their toxins. As a result, huge attention has been paid on the microbiological analysis of milk and dairy products to evaluate the quality and also to ensure that there are no public health hazards.

A milk shake is a sweet, cold beverage which is usually made from milk, ice cream, or iced milk, and flavorings or sweeteners such as butterscotch, caramel sauce, chocolate sauce, or fruit syrup.

Corresponding author: Dr. MARWA M.N. EL-GENDI

E-mail address: ahmednofel125@yahoo.com

Present address: Animal Health Research Institute (Assiut Provincial Lab.) Food Hygiene Department and Microbiology Department
Outside the United States, milkshakes using ice cream or iced milk are sometimes called a thick milkshake or thick shake; in New England, the term frappe may be used to differentiate it from thinner forms of flavored milk. Full-service restaurants, soda fountains, and diners usually prepare and mix the shake "by hand" from scoops of ice cream and milk in a blender or drink mixer using a stainless steel cup. Many fast food outlets do not make shakes by hand with ice cream. Instead, they make shakes in automatic milkshake machines which freeze and serve a premade milkshake mixture consisting of milk, a sweetened flavoring agent, and a thickening agent. However, some fast food outlets still follow the traditional method, and some serve milkshakes which are prepared by blending softserve ice cream (or ice milk) with flavoring or syrups. Milkshakes can also be made at home with a blender or automatic drink mixer (Bittman, 1998).

A milk shake can also be made by adding powder into fresh milk and stirring the powder into the milk. Milkshakes made in this way can come in a variety of flavors, including chocolate, caramel, strawberry, and banana. The manufacture of this product (milk shake) is based on traditional method without any regard to the quality of raw material used and/ or the hygienic quality of the products. Under such conditions many microorganisms can find access to the milk products.

Among all microorganisms E. coli is frequently contaminating organism, and is reliable indicator of 
fecal pollution generally in insanitary conditions of water, food, milk and other dairy products (Diliello. 1982). Two cases of hemolytic uraemic syndrome has been reported which provide evidence that raw milk may be a vehicle of transmission of E. coli O157: H7, both affected person consumed raw milk (Martin et al., 1986). Recovery of $E$. coli from food is an indicative of possible presence of enteropathogenic and/or toxigenic micro-organism which could constitute a public health hazard. Enteropathogenic E coli (EEC) can cause severe diarrhea and vomiting in infants and young children (Anonymous 1975). In 1971 USA faced outbreak of food poisoning in which 387 persons were suffered with Enteropathogenic E.coli due to the consumption of imported French cheese. E.coli was isolated from milk products like Mawa/ Khoa, Cream Dahi, Cheese, Butter and Gulabjaman. E. coli is a normal inhabitant of the intestines of animals and humans but its recovery from food may be of public health concern due to the possible presence of enteropathogenic and/or toxigenic strains which lead to sever gastrointestinal disturbance (Soomro et al., 2002). Its presence in processed foods results from recontamination, because this bacterium usually does not survive food preservation processes. The main reasons for the presence of E. coli in food products are nonobservance of relevant technological regimes, incompliance with recommended process standards, and the lack of personal hygiene (Law, 2000).

$S$. aureus is considered the third most important cause of disease in the world amongst the reported foodborne illnesses (Zhang et al., 1998). This grampositive bacterium has no particular nutritional and environmental requirement for its growth and it can grow at an $\mathrm{pH}$ above 4.8 and its minimum growth temperature is $18-45^{\circ} \mathrm{C}$ (Martin and Iandolo, 2000). Most strains are capable of producing one or more enterotoxins (Balaban and Rasooly, 2001) which are the cause of the gastrointestinal symptoms observed during intoxications (Tamarapu et al., 2001). Even though food-borne $S$. aureus poisoning is a mild, generally self-limiting disease, with symptoms that include vomiting with or without diarrhea (Dinges et al., 2000), hospitalization is required in approximately $10 \%$ of the cases (Holmberg and Blake, 1984).

Psychrotrophic bacteria are the most commonly isolated organisms which caused the spoilage of the heat treated milk and dairy products as the result of post-pasteurization contamination of the products (Santana et al., 2004). Due to these properties of psychrotrophs, the spoilage and reduced quality of milk and dairy products can be both the consequence of the presence of live organisms and/or their thermos table enzymes (Koka and Weimer, 2001). Spoilage is occurred as the change of flavour, undesirable coagulation of milk proteins, and the increased concentration of free fatty and amino acids. In addition, depending on the type of dairy product, the atypical texture and proportion of certain undesirable organic compounds are occurred (Cempírková and Mikulová, 2009). With regard to other quality aspects, such as suitability of milk for the production of dairy products, psychrotophs have a significant negative effects on yields as well as on limiting shelf life of dairy products (Causin, 1982).

Some authors stated that the presence of enterococci in food matrices is not always to be attributed to direct fecal contamination (Birollo et al., 2001 and Franz et al., 2003). Although they do not represent major pathogens for animals, enterococci are known to be a leading cause of nosocomial infections in humans; they have been implicated in infective endocarditis and urinary tract infections in immunocompromised patients (Coque et al., 1996).

Considering the above facts the present study was designed to isolate the E. coli, S. aureus and Enterococcus from some milk shakes sold under restaurants conditions at Assiut city.

\section{MATERIALS AND METHODS}

\section{A) Collection, preparation and serial dilutions of samples:}

Total of 50 random samples of chocolate milk shakes and fruity milk shake (25 samples each) were purchased from different restaurants in Assiut city, Egypt. These samples were freshly prepared and transferred aseptically in clean sterile packages. Microbiological examination were done for samples where eleven grams of the prepared samples were mixed with $99 \mathrm{ml}$ of sterile $0.1 \%$ peptone water and thoroughly mixed to give a dilution of $1 / 10$, and then tenfold serial dilutions were carried out according to (A.P.H.A., 1992).

\section{B) Microbiological techniques: \\ 1) Isolation and identification of $E$. coli according to ISO $7251(\mathbf{2 0 0 5})$ :}

Biochemical tests were performed to confirm $\boldsymbol{E}$. coli using Gram staining, Catalase test, Indole, Methyl red, Voges- Proskauer test, Nitrate reduction, Urease production, Simon citrate agar, and various sugar fermentation tests.

2) Enumeration, isolation and identification of Enterococci was carried out according to Deibel and Hartman (1982) using KF streptococcal agar and Azide dextrose broth.

3) Isolation and identification of $S$. aureus according to ISO 6888-1:1999 A1 (2003).

4) Enumeration of total yeasts and molds counts according to ISO 6611 (2004)

5) Total Psychrotrophic count according to ISO 6730 (2005). 


\section{RESULTS}

Table 1: Incidence of isolated microorganisms from the examined samples.

\begin{tabular}{cccccc}
\hline Microorganisms & \multicolumn{2}{c}{ Chocolate milk shake } & \multicolumn{2}{c}{ Fruity milk shake } \\
\cline { 3 - 6 } \cline { 3 - 6 } Products & No./25 & $\%$ & No./25 & $\%$ \\
\hline E. coli & 4 & $16 \%$ & 6 & $24 \%$ \\
Enterococcus & 5 & $20 \%$ & 11 & $44 \%$ \\
Staph. aureus & 3 & $12 \%$ & 6 & $24 \%$ \\
\hline
\end{tabular}

Table 2: Statistical analytical results of total yeasts and molds count of the examined samples.

\begin{tabular}{cccccc}
\hline \multirow{2}{*}{ Sample } & \multicolumn{3}{c}{ Positive samples } & \multicolumn{3}{c}{ Count/g } \\
\cline { 2 - 6 } & No./25 & $\%$ & Min. & Max. & Average \\
\hline Chocolate milk shake & 4 & $16 \%$ & $<100$ & $4 \times 10^{3}$ & $3.2 \times 10^{2}$ \\
\hline Fruity milk shake & 15 & $60 \%$ & $<100$ & $6 \times 10^{3}$ & $2.1 \times 10^{3}$ \\
\hline
\end{tabular}

Table 3: Statistical analytical results of total psychrotrophic count of the examined samples.

\begin{tabular}{cccccc}
\hline \multirow{2}{*}{ Sample } & \multicolumn{3}{c}{ Positive samples } & \multicolumn{3}{c}{ Count/g } \\
\cline { 2 - 6 } & No./25 & $\%$ & Min. & Max. & Average \\
\hline Chocolate milk shake & 6 & $24 \%$ & $<100$ & $2.23 \times 10^{5}$ & $9.9 \times 10^{3}$ \\
\hline Fruity milk shake & 7 & $28 \%$ & $<100$ & $1.6 \times 10^{5}$ & $1.2 \times 10^{4}$ \\
\hline
\end{tabular}

Table 4: Statistical analytical results of total Enterocci count of the examined samples.

\begin{tabular}{cccccc}
\hline \multirow{2}{*}{ Sample } & \multicolumn{3}{c}{ Positive samples } & \multicolumn{3}{c}{ Count/g } \\
\cline { 2 - 6 } & No./25 & $\%$ & Min. & Max. & Average \\
\hline Chocolate milk shake & 5 & $20 \%$ & $<100$ & $6.4 \times 10^{4}$ & $4.9 \times 10^{3}$ \\
\hline Fruity milk shake & 11 & $44 \%$ & $<100$ & $9.6 \times 10^{4}$ & $1.1 \times 10^{4}$ \\
\hline
\end{tabular}

\section{DISCUSSION}

Food borne pathogens are virtually inescapable reaching every aspects of life (Elhaleem and Elkarim 2011). Furthermore microbial contaminants are extremely difficult to pinpoint precision of their presence and role in food system (Biswas et al., 2011). The pattern of acute poisoning may be different even within the region or a country (Akhlaghi et al., 2009). It is therefore essential to increase the number of studies carried out on the importance of food poisoning (Sahingoz and Sahin 2009).

Food-borne outbreaks due to consumption of dairy products constitute a chronic problem facing food hygienists, as milk and dairy products are subjected to different sources of contamination by many pathogens either from endogenous origin or directly and indirectly from exogenous origin. The origin of contamination by food-borne pathogens varies with the type of product and the mode of production and processing. Treatment and processing of milk inhibit or encourage the multiplication of such organisms as all the nutritional components that make milk and dairy products an important part of the human diet, also support the growth of these pathogenic organisms (Feganand Desmarchelier, 2010 and Basil el al., 2012).

The results presented in Table 1 , showed that 4 isolates of $E$. coli out of 25 examined chocolate milk 
shake samples and 6 isolates out of 25 fruity milk shake samples were identified as $E$. coli with percentages of $16 \%$ and $24 \%$ respectively. Ahmed et al. (2009) found that different types of vended squeezed fruit juices samples have $E$. coli ranging from 43 to $>2400 / 100 \mathrm{ml}$ in Dhaka city, Bangladesh 17. Bagde and Tumane (2011) observed that fruit juices were found to be highly contaminated by $E$. coli in India. Higher results were also demonstrated by (Ahmad and Abdul Haq 2014).

Among all microorganisms E. coli is frequently contaminating organism, and is reliable indicator of fecal pollution generally in insanitary conditions of water, food, milk and other dairy products (Diliello. 1982). Recovery of E. coli from food is an indicative of possible presence of enteropathogenic and/or toxigenic micro-organism which could constitute a public health hazard (Georgi, 2011). The Findings of the present study revealed that the problem of $E$. coli contamination of milk shake products available in the chocolate and fruity milk shake exists. The presences of faecal indicator organisms not only indicate poor hygiene but also itself may be pathogenic.

Enterococcus spp. isolated from the examined chocolate milk shake samples and as recorded in Table 1, 5 (20\%) out of 25 examined samples were confirmed by biochemical tests, also, 11 (44\%) out of 25 examined samples of fruity milk shake were positive for Enterococcus spp. isolation.

An important clinical feature of Enterococcus spp. is the resistance to a wide range of antimicrobial agents as demonstrated in clinical, food and water isolates strains (Eaton and Gasson, 2001, Giraffa et al., 1997 and Gold and Moellering Jr. 1996). Enterococci can be detected not only in raw materials but also in RTE (ready to eat) foods, of animal (e.g., milk, cheeses, meat and fish products) and plant origin (e.g., vegetable, fruits; Giard et al., 2001; De Castro et al., 2002 and Abriouel et al., 2008). Despite the use of enterococci in the food industry, their effects on human biology vary widely. While some strains are used as probiotics, others are recognized as serious nosocomial pathogens causing bacteraemia, urinary tract infections, and endocarditis (Kucerova et al., 2009).

The results presented in Table 1, showed that staph. aureus was isolated within percentages of $12 \%$ and $24 \%$ from chocolate and fruity milk shake, respectively. Tambekar et al. (2009) reported Staphylococci prevalence in fruit juice samples in India. Ahmed et al. (2009) revealed the presence of staphylococci in squeezed fruit juice samples is also reported in Dhaka city. Rashed et al. (2013) found staphylococci in 30 out of 41 samples and total staphylococcal count for vended fruit juices samples was $6.95 \times 10^{5} \mathrm{cfu} / \mathrm{ml}$ in Dhaka city, Bangladesh.
Ahmad and Abdul Haq (2014) showed high prevalence of coagulase positive Staphylococcal Spp. where Staphylococcus Spp was found in $87 \%$ of strawberry, $79 \%$ of banana and $90 \%$ of apple samples. High load of Staphylococcal Spp for strawberry, banana and apple samples was $6.1 \times 10^{7}$, $2.2 \times 10^{5}$ and $1.2 \times 10^{7}$, respectively.

The presence of $S$. aureusmight indicate inadequate hygiene conditions during milkshake preparation. Foods requiring considerable handling during preparation and kept without refrigeration are usually involved in staphylococcal poisoning. This bacterium is able to grow in a wide temperature range $\left(7-48^{\circ} \mathrm{C}\right)$, with an optimal growth at $35-37{ }^{\circ} \mathrm{C}$, a frequent value in warm climates (Baeza et al., 2007). The presence of $\mathrm{S}$. aureus may be resulted from either insufficient pasteurization of milk, or human exposure. In humans, the main reservoir of $S$. aureus is the nasal cavity. The organism finds their way to the skin and into wounds either directly or indirectly. The most common skin sources are arms, hands, and face. In addition to skin and nasal cavities, S. aureus may be found in the eyes, throat and intestinal tract. From these sources, the organism finds its way into air and dust, onto clothing, and in other places from which it may contaminate foods (Jay, 1996). It is obvious from the previous and the present data that milk shake samples are frequently subjected to Staphylococci spp. contamination which may indicate inadequate personel hygiene of workers or sales people.

Out of 25 samples of chocolate milk shake studied, 4 of them were contaminated by total yeasts and molds counts with percentage $16 \%$ of samples with averages $3.2 \times 10^{2}$ varying between $<100$ to $4 \times 10^{3}$ $\mathrm{UFC} / \mathrm{mL}$, as shown in Table 2. In addition, the average of total yeasts and molds counts from the fruity milk shake was $2.1 \times 10^{3} \mathrm{cfu} / \mathrm{ml}$ and varied between $<100$ to $6 \times 10^{3} \mathrm{cfu} / \mathrm{mL}$, as shown in Table 2 . The counts of yeast and molds in the samples suggest the need for the control of adequate heat treatment of milk shake and appropriate storage conditions in catering premises.

Total Psychrotrophic counts varied between $<100$ to $2.23 \times 10^{5}$ with an average count $9.9 \times 10^{3} \mathrm{cfu} / \mathrm{mL}$ in the examined samples of chocolate milk shake as shown in Table 3. While Psychrotrophic counts reached to $1.6 \times 10^{5} \mathrm{cfu} / \mathrm{ml}$ as maximum count and counted in 7 (28\%) with average count $1.2 \times 10^{4} \mathrm{cfu} / \mathrm{ml}$ (Table 3 ). Psychrotrophic bacteria are generally able to form extracellular or intracellular termoresistant enzymes (proteases, lipases and phospholipases) which can cause spoilage of milk and dairy product. In addition, besides exhibiting spoilage features, some species belonging to the psychrotrophs are considered as opportunistic pathogenic bacteria that carry inherent resistance to antibiotics and/or to produce toxins. In sense of quality, psychrotrophic bacteria have become major problem for today's dairy industry as leading 
causes of spoilage and significant economic losses (Samaržija et al., 2012).

Only $20 \%$ (5 samples) of the examined samples of chocolate milk shake in the current study where contaminated with Enterococcus spp. with minimum count $<100 \mathrm{cfu} / \mathrm{ml}$ and maximum count $6.4 \times 10^{4} \mathrm{cfu} / \mathrm{ml}$ and average count $4.9 \times 10^{3} \mathrm{cfu} / \mathrm{ml}$. Comparing the results of chocolate milk shake with that obtained in fruity milk shake, it is found that $44 \%$ (11 samples) were positive for Enterococcus spp. with average count $1.1 \times 10^{4}$ and counts ranged from $<100$ to $9.6 \times 10^{4} \mathrm{cfu} / \mathrm{ml}$ as recorded in Table 4 . The count for Enterococcus spp. is being considered as one of the parameters used for food hygiene quality. Low hygienic quality of the samples regarding Enterococcus spp. occurrence in the previous and current work may have been resulted from insufficient heat treatment exposed to milk during the production or from post contamination.

The method of their manufacturing, handling, sale and transportation of these products are entirely based on the unhygienic measures. As observed during sample collection, the handling of products with bare hands, nonusage of aprons, absence of hair covering and handling of money during serving might also contribute to poor hygienic conditions. Such system could pose favorable environment for bacterial contamination. Poor personal hygiene, the use of unhygienic water, unhygienic surroundings act as source of contamination (Chukuezi 2010; Mensah et al., 2002). Thus more hygienic preventive measures are required to reduce the bacterial contamination, so as to increase the wholesomeness of these products.

In developing countries, fruit and vegetable juices are considered as an affordable and readily available source of nutrition especially in summer. Such unpasteurized juices with attributes of fresh flavor are sold by road side shops and is prepared simply by mechanical extraction method. Final product in the form of juice is consumed directly by the consumer without any treatment. Pathogenic microorganisms find their way into fruits and vegetables through damage surfaces that occur during the process of growth and harvesting. In addition equipment contamination, raw material contamination, improper handling, unhygienic conditions also facilitate the entry of pathogens into juices of fruit and vegetables (Nicolas et al., 2007 and Oliveira et al., 2012).

Most of these milk shakes are prepare uses milk of open shops directly without any treatment which may act as an additional source of contamination. The personal hygiene of the manufacturer and the servant who prepare these milk shakes is also not satisfactory as most them are illiterate and does not know anything about microbiological aspect of juices preparation (Ahmad and Abdul Haq 2014).

\section{CONCULUSION}

The results of the present investigation revealed that samples were found contaminated with E. coli, $S$. aureus and Enterococci. The highest rate of contamination was recorded form the samples of fruity milkshake. These organisms are significant from public health point of view as they have been associated with the onset of food poisoning in human beings. However a large volume of these products are produced in unorganized sector, unbranded, with little precautions of food safety and quality. The counts of microorganisms above the recommended criteria and the presence of some groups of pathogenic bacteria may pose a risk for public health particularly for children and vulnerable elderly people. It is clear from the previous and current studies that there is a necessity for developing the hygienic status of locally produced milk shake in domestic or catering premises in Assiut. This investigation is a factual documentation of such a finding and suggestions as to the methods needed to improve the safety and quality. Findings of this study highlighted the need to improve and implement the hygienic practices related to dairy production and to apply the Egyptian standards of such products for effective monitoring throughout from production to consumption. Due to the importance of the research, more work on food hygiene is still ongoing.

\section{RECOMENDIONS}

1- Effective and continuous training accompanied with emphasize on the safety and health issues related to raw milk hazards, educational efforts to improve dairy farmers' awareness of milk borne zoonoses, risk factors associated with milk borne pathogens.

2- Efficient cleaning of all utensils and equipment and the consumers should take in consideration the cleanliness of sales persons.

3- The final retail containers used are preferred to be dispensable and efficiently closed or covered.

4- It is of outmost importance to examine the stool specimens of apparently healthy dairy handlers to clarify their role in shedding bacterial pathogenic agents. To protect public health, more stringent regulations and strategies are in demand.

5- Preventive measures rather than curative measures should be adopted.

6- Strict check and balance of the milk shakes quality in Assiut city is required.

7- Educating the manufacturers and servants of milk shakes shops about safety techniques and microbiological aspects of juice preparation can help in reducing these problems.

8- The use of pure water and pasteurized milk for shakes preparation must be ensured.

9- Personal hygiene and sanitization of the manufacturer and servants should be maintained. 
10- Sterile equipments for milk shakes preparation should be used. The shops should be located in less crowded areas.

\section{REFERENCES}

A.P.H.A. (1992): Standard Methods for the Examination of Dairy Products. $13^{\text {th }}$ Ed., American Public Health Association. Academic Press: 2062-2065.

Abriouel, H.; Omar, N.B.; Molinos, A.C.; Lopez, R.L.; Jose, G.M.; Martinez-Viedma, P.; Ortega, E.; Canamero, M.M. and Galvez, A. (2008): Comparative analysis of genetic diversity and incidence of virulence factors and antibiotic resistance among enterococcal populations from raw fruit and vegetable foods, water and soil, and clinical 265 samples. International Journal of Food Microbiology 123, 38-49.

Ahmad, S. and Abdul Haq (2014): Microbiological Analysis of Milk Shakes in Peshawar City, Pakistan. American Journal of Phytomedicine and Clinical Therapeutics; 2(4): 486-494.

Ahmed, M.S.U.; Nasreen, T.; Feroza, B. and Parveen, S. (2009): Microbiological Quality of Local Market Vended Freshly Squeezed Fruit Juices in Dhaka City, Bangladesh. Bangladesh Journal of Scientific and Industrial Research. 2009; 44 (4): 421-424.

Akhlaghi, M.; Arbabi, Z. and Khadivi, R. (2009): Pattern of acute poisoning in Shahrekord (Western Iran). Asian J. Epidemiol. 2: 9-12.

Anonymous, (1975): E. coli Enteritis. Lancet, 1131-2.

Baeza, R.; Rossler, C.E.; Mielnicki, D.M.; Zamora, M.C. and Chirife, J. (2007): Simplified prediction of Staphylococcus aureus growth in a cooked meat product exposed to changing environmental temperatures in warm climates. Rev Arg Microbiol 39: 237242.

Bagde, N.I. and Tumane, P.M. (2011): Studies on microbial flora of fruit juices and cold drinks. Asiatic Journal of Biotechnology Resources. 2011; 2 (4): 454-460.

Balaban, N. and Rasooly, A. (2001): Analytical chromatography for recovery of small amounts of staphylococcal enterotoxins from food. Int. J. Food Microbiol.64, 33-40.

Basil, A.A.; Khudor, M.H. and Abid-Smeasem, O.I. (2012): Detection of verotoxigenic E. coli O157: H7 in raw milk using duplex PCR in Basra city-Iraq. Mirror Res. Vet. Sci. Anim., 1: 25-33

Birollo, G.A.; Peinheimer, J.A. and Vinderola, C.G. (2001): Enterococci vs. nonlactic acid microflora as hygiene indicators for sweetened yoghurt. Food Microbiol. 18, 597604.
Biswas, A.K.; Kondaiah, N.; Anjaneyulu, A.S.R. and Mandal, P.K. (2011): Causes, concerns, consequences and control of microbial contaminants in meat a review. Int. J. Meat Sci. 1: 27-35.

Bittman, M. (1998): milk shake might be milk, shaken up, with or without flavorings. pp. 668-669 in How to Cook Everything, Wiley, ISBN 978-0-471-78918-5.

Causin, M.A. (1982): Presence and activity of psyhrotrophic microorganisms in milk and dairy products: a review. Journal of Food Protection 45, 172-207.

Cempírková, R. and Mikulová, M. (2009): Incidence of psychrotrophiclipolytic bacteria in cow's milk. Czech Journal of Animal Science 54, 65-73.

Chukuezi, C.O. (2010): Food Safety and Hygienic practice of street food vendors in owerri, Nigeria. Studies in sociology of science. 1(1): 50-57.

Coque, T.M.; Tomayko, J.F.; Ricke, S.C.; Okhyusen, P.C. and Murray, B.E. (1996): Vancomycinresistant enterococci from nosocomial, community, and animal sources in the United States. Antimicrob. Agents Chemother. 40, 2605-2609.

De Castro, A.; Montano, A.; Casado, F.J.; Sanchez, A.H. and Rejano, L. (2002): Utilization of Enterococcus casseliflavus and Lactobacillus pentosus as starter cultures for Spanish-green olive fermentation. Food Microbiology 19, 637-644.

Deibel, R.H. and Hartman, P.A. (1982): The Enterococci. In: Compendium of Methods for the Microbiological Examination of Foods. M.L., Speck (ed.), $2^{\text {nd }}$ ed., American Public Health Association.

Diliello, L.R. (1982): Methods in Food and Dairy Microbiology. AVI publishing Co. Inc. Westport Connt. USA., p. 39.

Dinges, M.M.; Orwin, P.M. and Schlievert, P.M. (2000): Exotoxins of Staphylococcus aureus. Clin. Microbiol. Rev. 13, 16-34.

Eaton, T.J. and Gasson M.J. (2001): Molecular screening of Enterococcus virulence determinants and potential for genetic exchange between food and medical isolates. Appl. Environ. Microbiol. 67, 1628-1635.

Elhaleem - Abd, Z.A. and Elkarim-Abd M.A. (2011): Pattern of food poisoning in Egypt, a retrospective study. Journal of Pharmacology and Toxicology. 6(5): 505- 515

Fegan, N. and Desmarchelier, P. (2010): Pathogenic E. coli in the dairy industry: Implications for Australia. Aust. J. Dairy Technol., 65(2): 6873. 14.

Franz, C.M.; Stiles, M.E.; Schleifer, K.H. and Holzapfel, W.H. (2003): Enterococci in foods - a conundrum for food safety. Int. J. Food Microbiol. 88, 105-122. 
Georgi (2011): E. coli Outbreak. Available at: http://www.ezgoarticles.com/e-coli-outbreak

Giard, J.C.; Laplace, J.M.; Rince, A.; Pichereau, V.; Benachour, A.; Leboeuf, C.; Flahaut, S.; Auffray, Y. and Hartke, A. (2001): The stress proteome of Enterococcus faecalis. Electrophoresis 22, 2947-2954.

Giraffa, G.; Carminati, D. and Neviani E. (1997): Enterococci isolated from dairy products: a review of risks and potential technological use. J. Food Protec. 60, 732-738.

Gold, H.S. and Moellering Jr., R.C. (1996): Antimicrobial-drug resistance. N. Engl. J. Med. 335, 1445-1453.

Holmberg, S.D. and Blake, P.A. (1984): Staphylococcal food poisoning in the United States: new facts and old misconceptions. JAMA 251, 487-489.

Iso6730 (2005): Milk -- Enumeration of colony-forming units of psychrotrophic microorganisms -Colony-count technique at 6,5 degrees $\mathrm{C}$.

Iso6611 (2004): Milk and milk products -- Enumeration of colony-forming units of yeasts and/or moulds -- Colony-count technique at 25 degrees $\mathrm{C}$.

Iso6888-1:1999 A1 (2003): Horizontal methods for the enumeration of coagulase-positive Staphylococci (Staphylococcus aureus and other species). Technique using Baird-Parker medium.

Iso7251 (2005): Microbiology of food and animal feeding stuffs -- Horizontal method for the detection and enumeration of presumptive Escherichia coli -- Most probable number technique

Jay, J.M. (1996): Modern Food Microbiology, 5th ed., Chapman and Hall, New York.

Koka, R. and Weimer, B.C. (2001): Influence of growth conditions on heat stable phospholipase activity in Pseudomonas. Journal of Dairy Research 68, 109-116.

Kucerova, K.; Svobodova, H.; Tuma, S.; Ondrackova, I. and Plockova, M. (2009): Production of biogenic amines by enterococci. Czech Journal of Food Sciences 27, S2-50-S2-55.

Lowe, AM.; Lambert, PA. and Smith, AW. (1995): Cloning of an Enterococcus faecalis endocarditis antigen: homology with adhesions from some oral streptococci. Infection and Immunity 63, 703-706.

Law, D. (2000): Virulence factor of Escherichia coli O157 and other Shiga toxin-producing Escherichia coli. J. Appl. Microbiol.; 88: $729 \mathrm{e} 45$

Marcinek, H.; Wirth, R.; Muscholl-Silberhorn, A. and Gauer, M. (1998): Enterococcus faecalis Gene Transfer under Natural Conditions in Municipal Sewage Water Treatment Plants. Appl. Environ. Microbiol. 64(2), 626-632.

Martin, S.E. and Iandolo, J.J. (2000): Staphylococcus. In: Robinson, R.K., Batt,
C.A., Patel, P.D. (Eds.), Encyclopedia of Food Microbiology. Academic Press, pp. $2062-2065$.

Martin, M.L.; Shipman, L.D.; Potter, M.E.; Wachsmuth, L.K.; Wells, J.G.; Hedberg, K.; Tauxe, R.V.; Davis, J.P. Arnoldi, J. and Tilleli, J. (1986): Isolation of Escherichia coli O157:H7 from dairy cattle associated with two cases of hemolytic uraemic syndrome. Lancet., 8514, 1O43. Anonymous, 1975. E. coli Enteritis. Lancet, 1131-2.

Mensah, P.; Yeboah, M.D.; Owusu, D.K. and Ablordey, A. (2002): Street foods in Accra, Ghana: how safe are they? Bulletin of the World Health Organization. 80 (7): 546- 554.

Nicolas, B.; Razack, B.A.; Yollande, I.; Aly, S.; Tidiane, O.C.A.; Philippe, N.A.; De Souza, C. and Sababénédjo, T.A. (2007): Street-Vended Foods Improvement: Contamination Mechanisms and Application of Food Safety Objective Strategy: Critical Review. Pakistan Journal of Nutrition.; 6(1): 1-10.

Oliveira, A.C.G.; Seixas, A.S.S.; Sousa, C.P. and Souza, C.W.O. (2012): Microbiological evaluation of sugarcane juice sold at street stands and juice handling conditions in São Carlos, São Paulo, Brazil. Cad. Saúde Pública, Rio de Janeiro.2012; 22(5): 11111114.

Oliver, S.P.; Jayarao, B.M. and Almeida, R.A. (2005): Foodborne pathogens in milk and the dairy farm environment: Food safety and public health implications. Foodborne Pathog. Dis., 2: 115-129.

Rashed, N.; Aftab, U.M.; Azizul, H.M.; Saurab, K.M.; Mrityunjoy, A. and Majibur, R.M. (2013): Microbiological study of vendor and packed fruit juices locally available in Dhaka city, Bangladesh. International Food Research Journal. 20(2).

Sahingoz, S.A. and Sahin, H. (2009): Consumer awareness on food poisoning. Pak. J. Nutr., 8: 1218-1223.

Samaržija, D.; Zamberlin, S. and Pogačić, T. (2012): Psychrotrophic bacteria and milk quality. Mljekarstvo 62 (2), 77-95.

Santana, E.H.W.; De. Beloti, V.; Müller, E.E.; Ferreira, M.A.de.; Morales, L.B.de., Pereira, M.S. and Gusmão, V.V. (2004): Milk contamination in different points of dairy process. ii) mesophilic, psychrotrophic and proteolytic microorganisms. Semina: Ciências Agrárias; Londrina 25, 349-358.

Soomro, A.H.; Arain, M.A.; Khaskheli, M. and Bhutto, B. (2002): Isolation of Escherichia coli from raw milk and milk products in relation to public health sold under market conditions at Tandojam. Pak J Nut;1:151e2.

Tamarapu, S.; McKillip, J.L. and Drake, M. (2001): Development of a multiplex Polymerase chain reaction assay for detection and 
differentation of Staphylococcus aureus in dairy products. J. Food Prot. 64, 664- 668.

Tambekar, D.H.; Jaiswal, V.J.; Dhanorkar, D.V.; Gulhane, P.B. and Dudhane, M.N. (2009): Microbial Quality and safety of street vended fruit juices: A case study of Amravati city. Internet Journal of Food Safety.10:72-76.
Zhang, S.; Iandolo, J. and Stewart, C. (1998): The enterotoxin D plasmid of Staphylococcus aureus encodes a second enterotoxin determinant (sej). FEMS Microbiol. Lett. $168,227-233$.

\title{
المخاطر المكروبيولوجية لمخفوق اللبن المباع في مطاعم مدينة اسيوط
}

\author{
مروقة محمد نبيل الجندي ، مريم فؤاد منسي
}

Email: ahmednofe1125@yahoo.com Ässiut University web-site: www.aun.edu.eg

\begin{abstract}
الميلك شيك أو مخفوق الحليب شر اب بارد حلو ويمكن تحضيره بنكهات عديدة كالفراولة أو الثوكو لاتة ولكن يبقى اللبن من مكوّناته

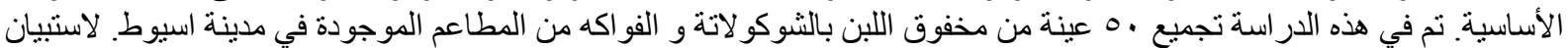

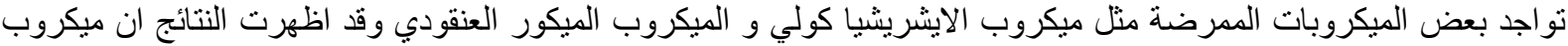

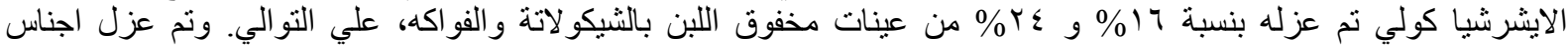

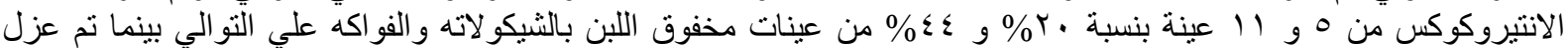

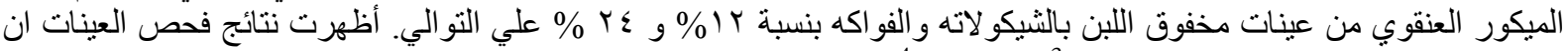

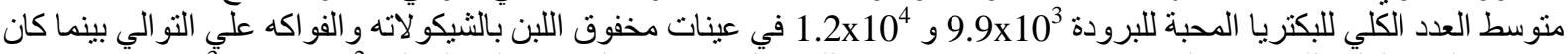

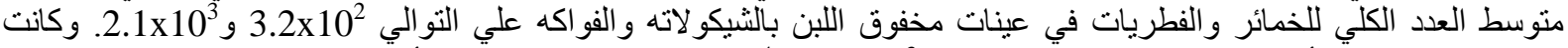

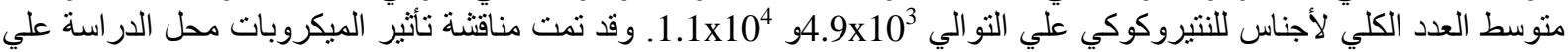
الصحة العامة و وضع التوصيات اللازمة للحد من انتشار هذه الميكروبات و الحصول علي منتج صحي آمن للمستهلك.
\end{abstract}

